\title{
Appendix A. Supplementary Materials
}

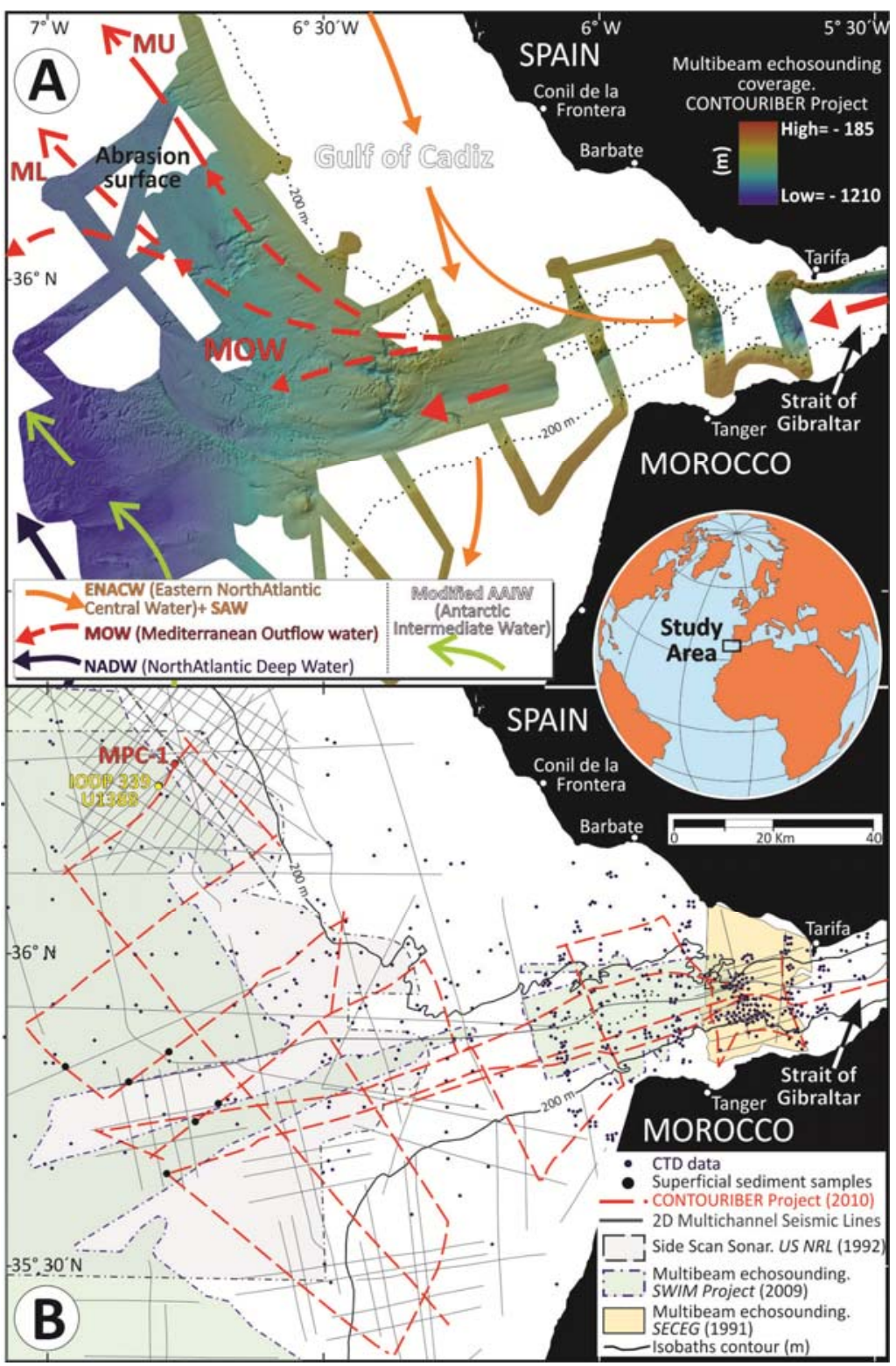

Figure DR1. Study area with the data sets ( $a$ and $b$ ) used in this work and the regional water-mass circulation sketched. The data that we used in this study were acquired mainly during the CONTOURIBER-1 Cruise (2010) onboard RV "Sarmiento de Gamboa" and include: I) swath bathymetry (showed in a); II) very high-resolution (Parasound) and midresolution (airgun) seismics; III) superficial sediment samples; and IV) Acoustic Doppler Current Profiler (ADCP) data. Published bathymetric data sets (showed in b) from the SWIM Project (Zitellini et al., 2009) were also utilized, including higher-resolution data from TV-GIB (Gutscher, 2005), the CADISAR-1 (Mulder et al., 2003) and Sonar-91 (IFREMER, 1991, SECEG/SNED) cruises, in addition to a regional geophysical compilation. Industry borehole MPC-1 (1982) provided details on margin evolution and age constraints. Finally, a very detailed hydrographic analysis was performed, based on: I) the ADCP data; II) an extensive Conductivity, Temperature and Depth (CTD) dataset collected by the Universities of Lisbon and Cádiz since 1970; III) an integrated acoustic analysis of the water column, conducted at the University of Bremen, for detection of water-mass interfaces, nepheloid layers and internal waves; and IV) numerical simulations of bottom temperature, salinity and currents, performed at the University of Hamburg. 


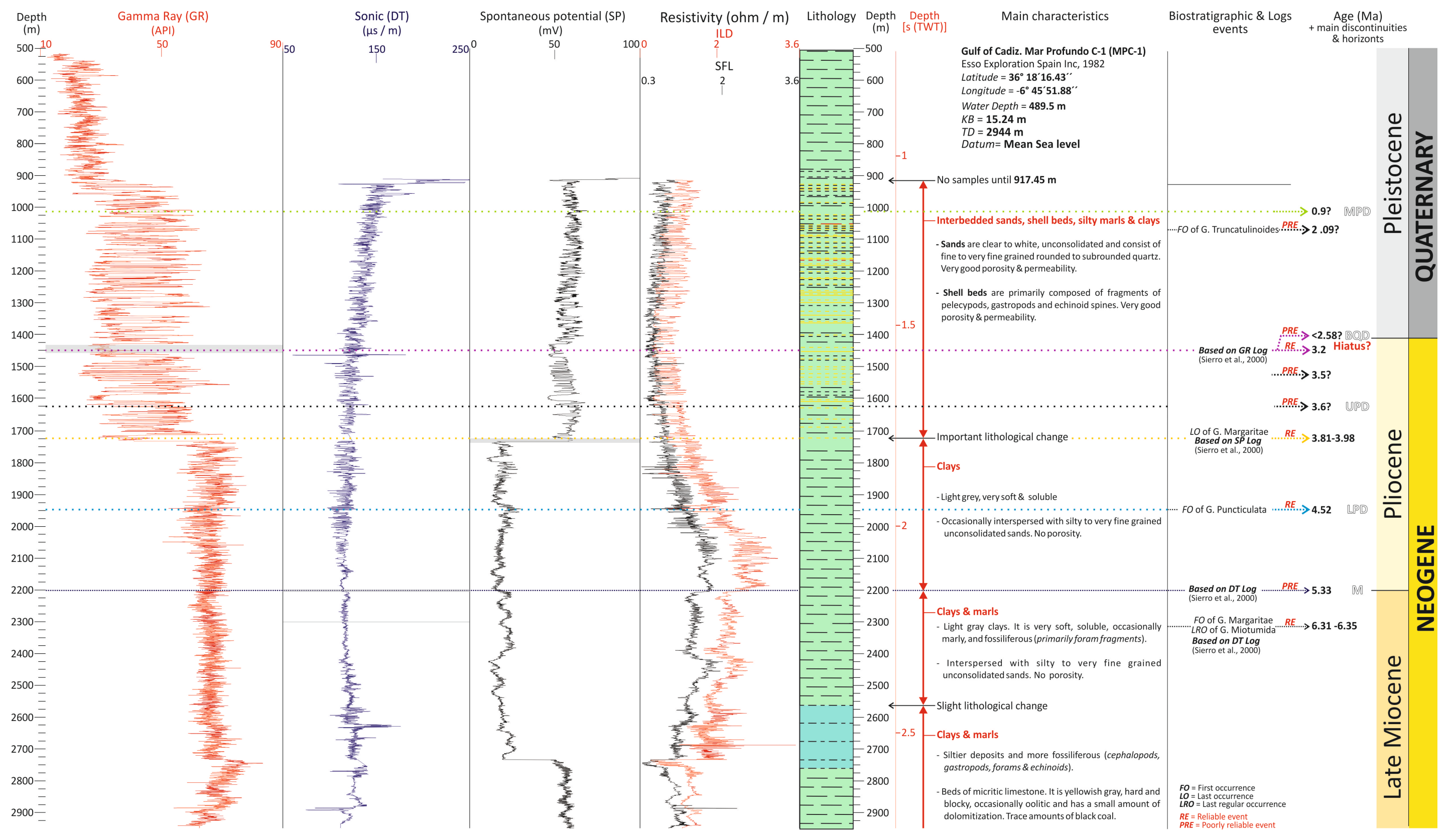

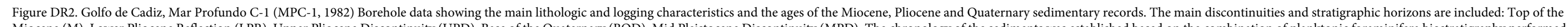
Miocene (M) : Lower Pliczene

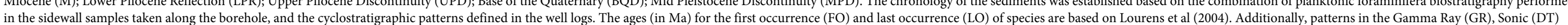

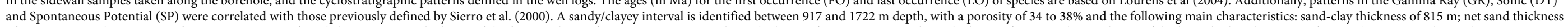

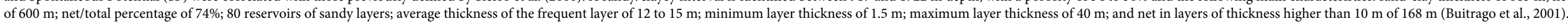



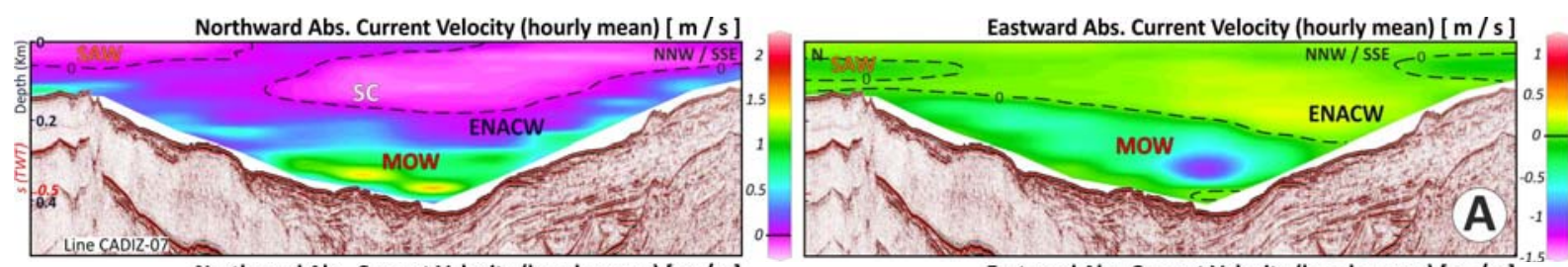

Northward Abs. Current Velocity (hourly mean) $[\mathrm{m} / \mathrm{s}]$
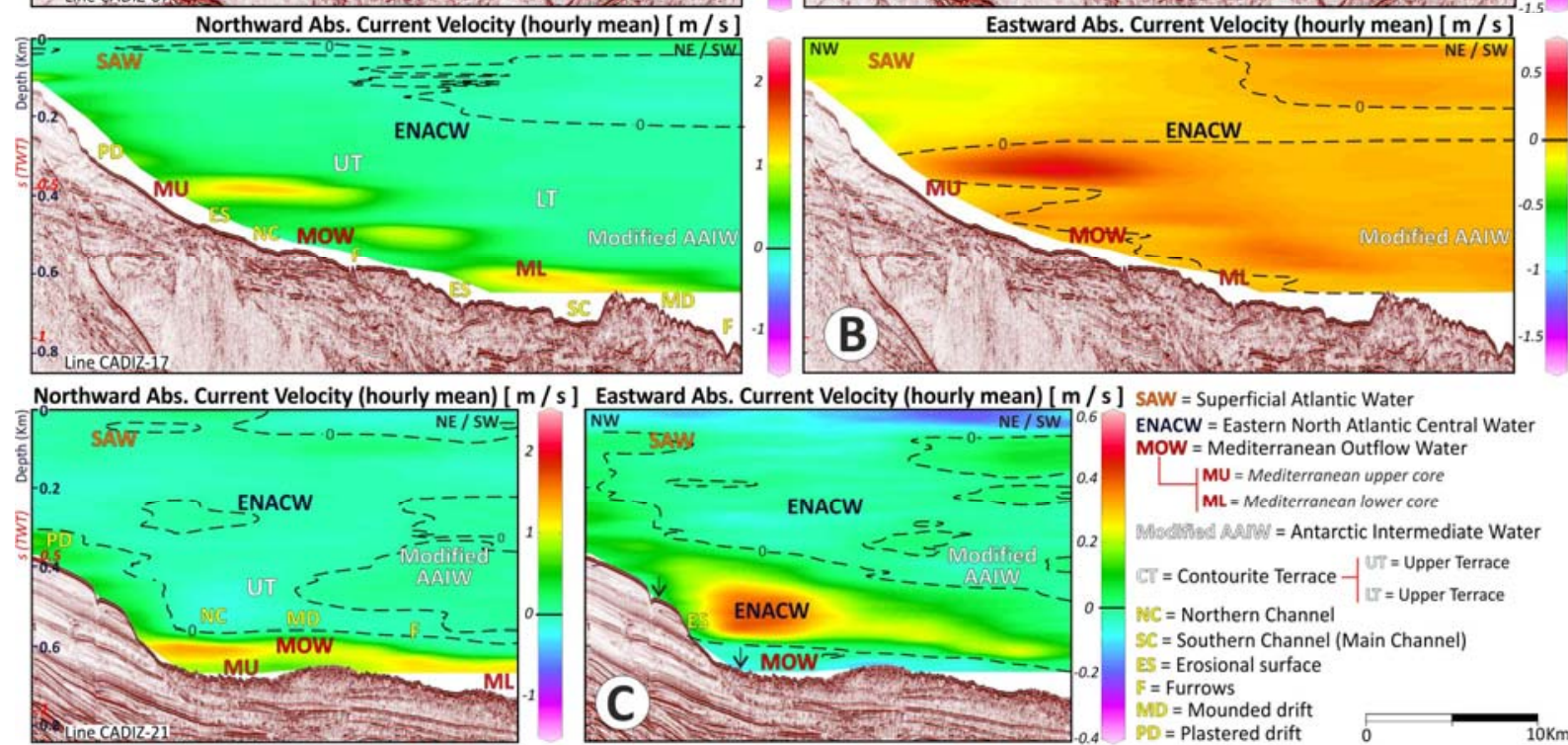

ENACW $=$ Eastern North Atlantic Central Water MOW $=$ Mediterranean Outflow Water

MU = Mediterranean upper core $\mathrm{ML}=$ Mediterranean lower core

Modifled MAMO = Antarctic Intermediate Water

$C T=$ Contourite Terrace $-f^{U T}=$ Upper Terrace

$\checkmark C=$ Northern Channel

$S C=$ Southern Channel (Main Channel)

ES = Erosional surface

= Furrows

$M D=$ Mounded drift
$P D=$ Plastered drift

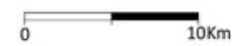

Figure DR3. Vertical sections of ocean velocity measured at the eastern area close to the exit of the Strait of Gibraltar (a) and further west ( $b$ and c). See Figure 1 for section locations. The water color code displays the Acoustic Doppler Current Profiler (ADCP) velocity components. Water-mass interpretations are shown on the left sections and major contourite features, on the right sections. The ocean velocities were measured by a $75 \mathrm{KHz}$ hull-mounted ADCP. The panels on the left correspond to the velocity component in the east-west direction (positive values indicate currents towards the east), and the panels on the right correspond to the velocity component in the north-south direction (positive values indicate current towards the north). The dashed black lines indicate where the current velocity is zero. 

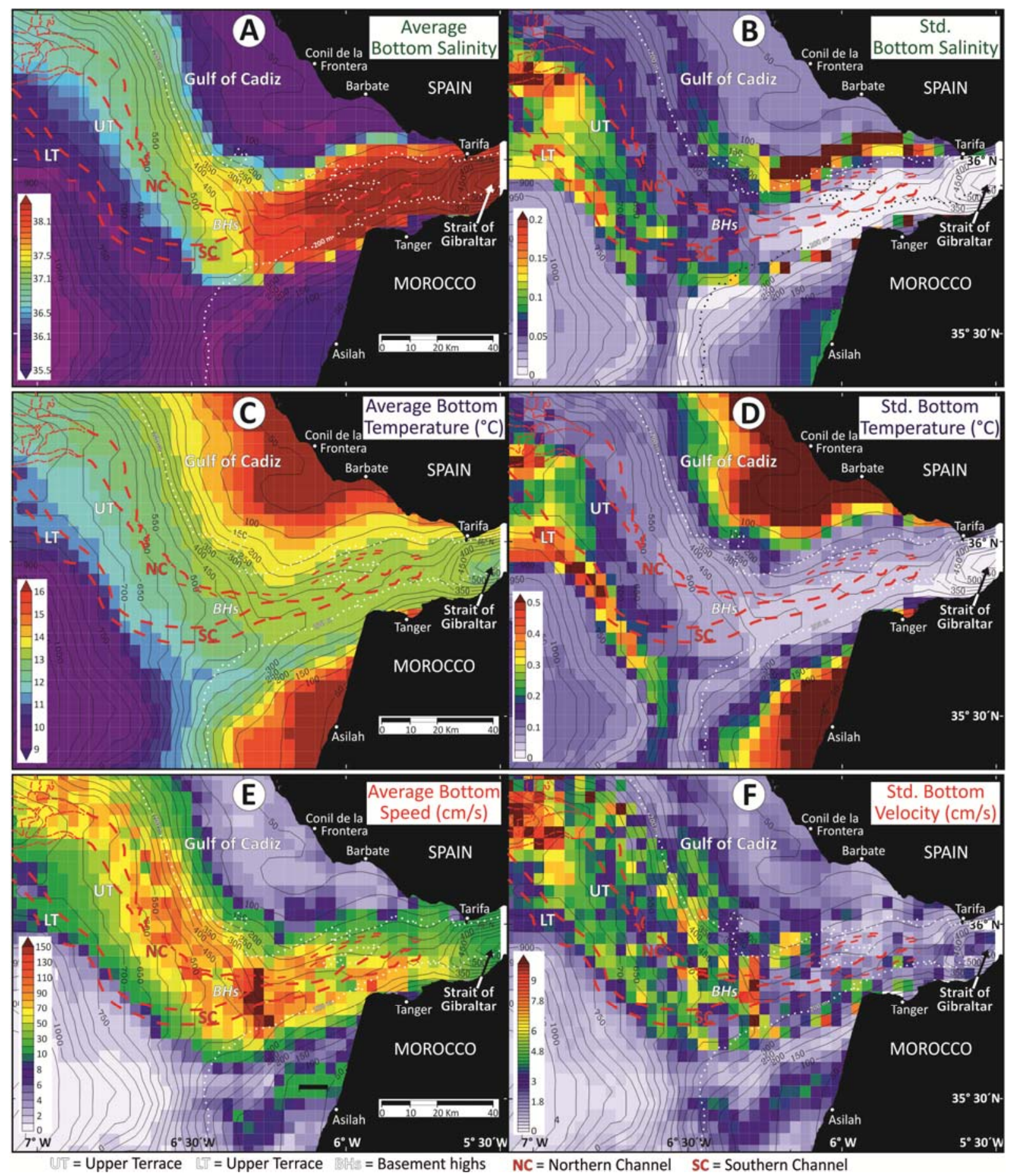

Figure DR4. Average (left) and standard deviation (right) of simulated bottom salinity (a,b), temperature (c,d) and speed $(e, f)$ adjacent to the Strait of Gibraltar. Major erosional features (terraces and channels) are indicated. White dots represent the 200-m isobath. We used output of the MIT general circulation model (Marshall et al., 1997), configured to the Northeast Atlantic and Western Mediterranean regions from $9^{\circ} \mathrm{E}$ to $24^{\circ} \mathrm{W}$ and $30^{\circ} \mathrm{N}$ to $48^{\circ} \mathrm{N}$ with a horizontal resolution of about $2.8 \mathrm{~km}$ (Serra et al., 2010a). The vertical resolution varies from $5 \mathrm{~m}$ in the upper ocean to $100 \mathrm{~m}$ in the deep ocean (140 levels). The bottom topography was extracted from ETOPO2 and the initial temperature and salinity from the World Ocean Atlas 2005 (Boyer et al., 2005). The model was run for the period 1990 to 2009 forced at the surface by fluxes of momentum, heat and freshwater computed with bulk formulae and the NCEP reanalysis 6-hourly atmospheric state (Kalnay et al., 1996) and laterally by the output of a 16-km Atlantic solution of the MITgcm forced by the same NCEP dataset (Serra et al., 2010b). Vertical mixing uses the KPP formulation of Large et al. (1994) and Laplacian vertical diffusion and viscosity have coefficients of $1 \times 10^{-4} \mathrm{~m}^{2} / \mathrm{s}$. A 
quadratic bottom drag coefficient of 0.002 and biharmonic coefficients of horizontal diffusion and viscosity of $1 \times 10^{3}$ $\mathrm{m}^{4} / \mathrm{s}$ and $5 \times 10^{8} \mathrm{~m}^{4} / \mathrm{s}$ were employed. The simulation realism concerning the MOW circulation is discussed in Serra et al. (2010a). All analyses presented here were based on daily model output and corroborated our conclusion that, presently, the MOW flows mainly along the upper slope and the upper terrace (UT) in the middle slope, without any permanent circulation over the lower terrace (LT).

Table DR1. Regional characteristic values of potential temperature $(\theta)$, salinity $(S)$, dissolved oxygen $\left(\mathrm{O}_{2}\right)$ and neutral density $\left(\gamma^{n}\right)$ for the main water masses in the sector of the Gulf of Cadiz close to the Strait of Gibraltar.

\begin{tabular}{|c|c|c|c|c|}
\hline Water Masses & $\begin{array}{c}\text { Temperature ( } \mathrm{T}) \\
{ }^{\circ} \mathrm{C}\end{array}$ & Salinity (S) & $\begin{array}{c}\text { Dissolved oxygen }\left(\mathrm{O}_{2}\right) \\
\mathrm{ml} / \mathrm{l}\end{array}$ & $\begin{array}{c}\text { Neutral density }\left(\gamma^{n}\right) \\
\mathrm{Kg} / \mathrm{m}^{3}\end{array}$ \\
\hline Surface Atlantic Water (SAW) & $18-20$ & $\sim 36.4$ & 4.6 & $1025.8-1026.3$ \\
\hline East North Atlantic Central Water (ENACW) & $10.6-16.5$ & $35.6-36.3$ & 5.06 & $1026.4-1027.6$ \\
\hline Mediterranean Outflow Water (MOW) & $13.1^{\circ}$ & $\sim 38.5$ & 4.15 & 1029.1 \\
\hline Modified Antarctic Intermediate Water (AAIW) & $\sim 10^{\circ}$ & $\sim 35.62$ & $\sim 4.16$ & 1027.5 \\
\hline (North) Atlantic Deep Water (NADW) & $1.5-4^{\circ}$ & $34.8-35.2$ & 5.52 & $1027.3-1027.9$ \\
\hline
\end{tabular}

\section{REFERENCES}

Boyer, T., Levitus, S., Garcia, H., Locarnini, R., Stephens, C., and Antonov, J., 2005, Objective analyses of annual, seasonal, and monthly temperature and salinity for the World Ocean on a $0.25^{\circ}$ grid: International Journal of Climatology, 25(7), p. 931-945. doi:10.1002/joc.1173

Buitrago, J., García, C., Cajebread-Brow, J., Jiménez, A., and Martínez del Olmo, W., 2001, Contouritas: Un excelente almacén casi desconocido (Golfo de Cádiz, SO de España): 1er Congreso Técnico Exploración y Producción REPSOLYPF, Madrid, p. 24-27.

Gutscher, M.A., 2005, Destruction of Atlantis by a great earthquake and tsunami?. A geological analysis of the Spartel Bank hypothesis: Geology, v. 33, p. 685-688, doi: 10.1130/G21597AR.1

Kalnay, E., Kanamitsu, M., Kistler, R., et al., 1996, The NCEP/NCAR 40-year reanalysis project: Bulletin of the American Meteorological Society, v. 77, p. 437-470, doi: 10.1175/1520-0477(1996)077<0437:TNYRP>2.0.CO;2

Large, W., McWilliams, J., and Doney, S., 1994, Ocean vertical mixing: A review and a model with a nonlocal boundary layer parameterization: Revews of Geophyisics, v. 32, p. 363-403, doi:10.1029/94RG01872

Lourens, L., Hilgen, F., Shackleton, N.J., Laskar, J., and Wilson, D., 2004, The Neogene period. in Gradstein, F.M., Ogg, J.G., and Smith, A., Eds., A Geologic Time Scale 2004: Cambridge (Cambridge Univ. Press), p. 409-440, http://dx.doi.org/10.1017/CBO9780511536045.022

Marshall, J., Adcroft, A., Hill, C., Perelman, L., and Heisey, C., 1997, A finite-volume, incompressible Navier Stokes model for studies of the ocean on parallel computers: Journal of Geophysical Research Oceans, v. 102, p. 57535766, doi:10.1029/96JC02775

Mulder, T., Voisset, M., Lecroart, P., Le Drezen, E., Gonthier, E., Hanquiez, V., Faugères, J.C., Habgood, E., HernandezMolina, F.J., Estrada, F., Llave, E., Poirier, D., Gorini, C., Fuchey, Y., Volker, A., Freitas, P., Lobo Sanchez, F., Fernandez, L.M., and Morel, J., 2003, The Gulf of Cadiz: an unstable giant contouritic levee: Geo-Marine Letters, v. 23, p. 7-18, doi: 10.1007/s00367-003-0119-0

Serra, N., Ambar, I., and Boutov, D., 2010a, Surface expression of Mediterranean Water dipoles and their contribution to the shelf/slope - open ocean exchange: Ocean Science, v. 6, p. 191-209, doi:10.5194/osd-6-2579-2009

Serra, N., Käse, R.H., Köhl, A., Stammer, D., and Quadfasel, D., 2010b, On the low-frequency phase relation between the Denmark Strait and the Faroe-Bank Channel overflows: Tellus, v. 62A, p. 530-550, doi:10.1111/j.16000870.2010.00445.x

Sierro, F.J., Ledesma, S., Flores, J.A., Torrescusa, S., and Martínez Del Olmo, W., 2000, Sonic and gamma-ray astrochronology: Cycle to cycle calibration of Atlantic climatic records to Mediterranean sapropels and astronomical oscillations: Geology, v. 28, p. 695-698, doi:10.1130/0091-7613(2000)28<695:SAGACT>2.0.CO;2

Zitellini, N., Gràcia, E., Matias, L., Terrinha, P., Abreu, M.A., DeAlteriis, G., Henriet, J.P., Dañobetia, J.J., Masson, D.G., Mulder, T., Ramella, R., Somoza, L., and Diez, S., 2009, The quest for the Africa-Eurasia plate boundary west of the Strait of Gibraltar: Earth and Planetary Science Letters, v. 280, p. 13-50, doi:10.1016/j.epsl.2008.12.005 